\begin{tabular}{|c|}
\hline 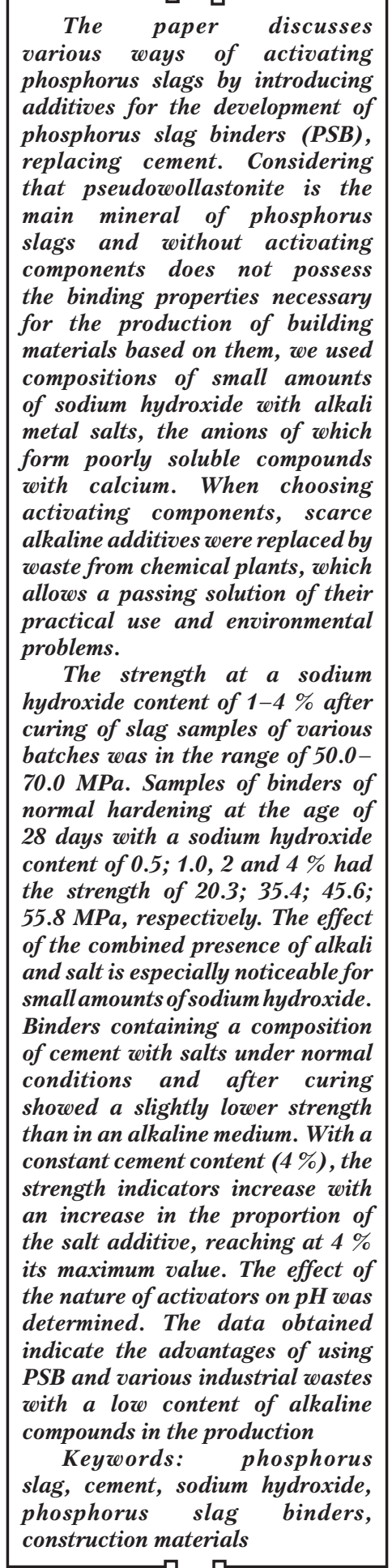 \\
\hline
\end{tabular}

UDC 69: 624,01: 691:624,01:691

DOI: $10.15587 / 1729-4061.2021 .242814$

\title{
DEVELOPMENT AND RESEARCH OF THE INFLUENCE OF THE COMPOSITION AND CONCENTRATION OF ACTIVATORS ON THE STRENGTH OF PHOSPHORUS SLAG BINDERS
}

\author{
UItuar Mahambetova \\ Doctor of Technical Sciences, Professor* \\ B u I bu I Nuran ba ye va \\ Corresponding author \\ Professor, Program Leader Petroleum Engineering \\ Department of Petroleum Engineering \\ Caspian University
}

Dostyk ave., 85A, Almaty, Republic of Kazakhstan, 050000

E-mail: bulbulmold@mail.ru

Zatkali Estemesov

Doctor of Technical Sciences, Professor, Director Central Laboratory of Certification Tests Building Materials" LLP - "Tselsim"

Ryskulova str., 95, Almaty, Republic of Kazakhstan, 050058

Pernekhan Sadykov

Doctor of Technical Sciences, Professor

Orken Mamyrbayev

$\mathrm{PhD}$, Deputy General Director in Science

Laboratory of Computer Engineering of Intelligent Systems

Institute of Information and Computational Technologies

Pushkina str., 125, Almaty, Republic of Kazakhstan, 050010

Dina Oralbekova

Researcher

Department of Cybersecurity, Information Processing and Storage

Satbayev University

Satpayev str., 22, Almaty, Republic ofKazakhstan, 050013

*Department of "Design and Construction"Baishev University Bratev Zhubanovykh str., 302a, Aktobe, Republic of Kazakhstan, 030000

Received date 09.09.2021 Accepted date 19.10.2021 Published date 29.10.2021
How to Cite: Makhambetova, U., Nuranbayeva, B., Estemesov, Z., Sadykov, P., Mamyrbayev, O., Oralbekova, D. (2021). Development and research of the influence of the composition and concentration of activators on the strength of phosphorus slag binders. Eastern-European Journal of Enterprise Technologies, 5 (6 (113)), 54-61. doi: https://doi.org/10.15587/1729-4061.2021.242814

\section{Introduction}

Granular phosphorous slags are by-products (manmade) obtained in the production of phosphorus by the method of sublimation in electrothermal furnaces. Their granulation is carried out at a temperature of about
$1,450{ }^{\circ} \mathrm{C}$ by draining the fiery liquid slags into a pool of water.

Phosphorus and its compounds (phosphorus fertilizers) are mainly obtained from phosphorite (calcium salt of phosphoric acid $\mathrm{Ca}_{3}\left(\mathrm{PO}_{4}\right)_{2}$ or $\left.3 \mathrm{CaOP}_{2} \mathrm{O}_{5}\right)$, the richest deposits of which in Kazakhstan are located in the Karatau Mountains. 
In electric furnaces at a temperature of about $1,450{ }^{\circ} \mathrm{C}$, the following reaction takes place in the corresponding mixtures of phosphorite $\left(3 \mathrm{CaOP}_{2} \mathrm{O}_{5}\right)$, sand $\left(\mathrm{SiO}_{2}\right)$ and carbon $(\mathrm{C})$ :

$$
\mathrm{Ca}_{3}\left(\mathrm{PO}_{4}\right)_{2}+3 \mathrm{SiO}_{2}+5 \mathrm{C} \rightarrow 3 \mathrm{CaOSiO} \mathrm{SiO}_{2}+2 \mathrm{P}^{\wedge}+5 \mathrm{CO} .
$$

The chemical composition of phosphorus slags is characterized by constancy. The binding properties of monominerals and glasses in the composition of phosphorus slag were studied by $[1,2]$. The products of the hydration of $\alpha-\mathrm{CaO}$ $\mathrm{SIO}_{2}$ with $\mathrm{Ca}(\mathrm{OH})_{2}$ are fibrous calcium hydrosilicates of the type CSN (1) and high-base calcium hydrosilicate-a-hydrate $\mathrm{C}_{2} \mathrm{~S}$ [1-3]. It was found that pseudowollastonite, which is the main mineral of phosphorus slags without activating components does not have astringent properties, but in the presence of calcium hydroxide it acquires them and is able to harden independently.

Three methods have been developed for the purification of granular slags from harmful impurities of phosphine and hydrogen fluoride: liquid-phase, thermal and mechanochemical. The most common is the mechanochemical method of cleaning. Mechanochemical purification of granular phosphorous slags is based on the reactions of phosphine oxidation and neutralization of hydrogen fluoride by introducing oxidizing and neutralizing additives into the slags during their drying and grinding [4].

The production technology of phosphorus slag binders is based on theoretical assumptions about the destruction of silicon- and calcium-oxygen polyhedral groups of slag under the influence of various activating components [2,3].

The activating components of the slag binder, depending on their nature and the mechanism of action on the hardening system, are divided into six groups [5]:

1. Caustic alkalis $(\mathrm{ROH})$.

2. Unsilicate salts of weak acids $\left(\mathrm{R}_{2} \mathrm{CO}_{3}, \mathrm{R}_{2} \mathrm{SO}_{3}, \mathrm{R}_{2} \mathrm{~S}, \mathrm{RF}\right)$.

3. Silicate salts $\left(\mathrm{R}_{2} \mathrm{O}[0,5-4,0] \cdot \mathrm{SiO}_{2}\right)$.

4. Aluminate salts $\left(\mathrm{R}_{2} \mathrm{OA} 1_{2} \mathrm{O}_{3}\right)$.

5. Aluminosilicate salts $\left(\mathrm{R}_{2} \mathrm{OA} 1_{2} \mathrm{O}_{3} \mathrm{SiO}_{2}\right)$.

6. Non-silicate salts of strong acids ( $\left.\mathrm{RC} 1, \mathrm{R}_{2} \mathrm{SO}_{4}\right)$ [2-5].

Therefore, studies devoted to the activation process of an inert phosphorus slag using a composition of small amounts of sodium hydroxide with alkali metal salts, the anions of which form poorly soluble compounds with calcium, are of scientific significance.

\section{Literature review and problem statement}

In [6], studies are devoted to the experimental assessment of the effect of activators on the strength properties of slag concretes during their hardening under conditions of steaming and autoclaving. As activators, sulfates and chlorides of alkali and alkaline earth metals $\mathrm{Na}_{2} \mathrm{SO}_{4}, \mathrm{~K}_{2} \mathrm{SO}_{4}$, $\mathrm{MgSO}_{4}$, mirabilite, as well as chlorides of alkali and alkaline earth metals $\mathrm{MgCl}_{2}, \mathrm{CaCl}_{2}$, carnalite, natural bischofite are used. It is shown that with the introduction of chlorides to activate the slag in an amount of $1 \%$ of the slag weight and hardening of concrete under conditions of elevated temperatures and steam pressure, high-strength concretes with strength from 58 to $80 \mathrm{MPa}$ are obtained. It is important to note that salts containing $\mathrm{MgCl}_{2}, \mathrm{CaCl}_{2}$ chlorides, carnalite, natural bischofite have a negative effect on corrosion resistance and require additional introduction of inhibitors, the results of which are not presented by the authors.
The authors [7] propose additives - APEG-type PCE and HPEG-type PCE, which can effectively improve the fluidity of the slag. The work is devoted to the selection of additives to reduce the increased viscosity, due to the activation of $\mathrm{NaOH}$ with a high concentration. From an economic point of view, the recommendations by the authors on the parallel introduction of two types of additives, in terms of functionality, that reduce the effectiveness of one of them are unprofitable.

The paper [8] publishes data on the technical characteristics of phosphorus slags: composition, activity, safety levels, utilization, as well as the results of testing hybrid cements, activated with alkali, containing phosphorus slag in the binder:

1) C, Portland cement clinker;

2) PS, phosphorus slag;

3) G, gypsum; CG, calcined gypsum;

4) NS, sodium sulfate;

5) CAS, calcined alumina.

It was noted that they showed improved stability compared to Portland cement samples when exposed to sulfate solutions. The addition of phosphorus slag also reduced the tendency for harmful alkali reaction with the unit. The work [8] shows the safe use of alkaline activators in metal aggregates used in the production of concrete mixtures based on phosphorus slag.

The work [9] experimentally studied the effect of 5-7\% alkali addition and sodium silicate modulus in the activator solution on workability, compressive strength and shrinkage during drying of slag concrete. In the test results, in most mixtures, due to an increase in the modulus of sodium silicate and the concentration of an alkaline solution: sediment, compressive strength and shrinkage rate during drying of the samples were increased, but it is necessary to note a reduction in the setting time, which leads to disruption of the technological process.

The objectives of the study [10] were to obtain a binder based on phosphorus slag and to study the suitability of polymetallic ore tailings containing calcium carbonate and sodium barium compounds, and their combination as activators, by studying the effect of the type and dosage of activators on compressive strength. This work shows the promise of expanding the area of using waste with an alkaline reaction for the activation of phosphorus slag.

In [11], a statistical experimental design was applied to predict and optimize the compressive strength of alkali-activated phosphorus slag at different ages (3, 7, and 28 days). For this, samples of a binder were prepared with different molar ratios $\mathrm{SiO}_{2} / \mathrm{Na}_{2} \mathrm{O}(\mathrm{S} / \mathrm{N}), \mathrm{Na}_{2} \mathrm{O} / \mathrm{Al}_{2} \mathrm{O}_{3}(\mathrm{Na} / \mathrm{Al})$ and $\mathrm{H}_{2} \mathrm{O} / \mathrm{Al}_{2} \mathrm{O}_{3}(\mathrm{H} / \mathrm{Al})$ as alkaline activators. The optimal chemical composition of the activator for obtaining maximum compressive strength was achieved as $0.39,1.34$ and 30 for molar ratios $\mathrm{S} / \mathrm{N}, \mathrm{Na} / \mathrm{Al}$ and $\mathrm{H} / \mathrm{Al}$, respectively, with compressive strength of 30,65 and $100 \mathrm{MPa}$ through 3,7 and 28 days of curing. As can be seen from the given strength data, the use of alkaline activators is highly effective even without heat treatment. The use of pure chemical compounds with a high content of alkaline activators is justified only for laboratory research and is excluded in a market economy.

The study [12] is devoted to the technical properties of alkali-activated slags (AAS) obtained by mixing an activator consisting of sodium silicate and sodium hydroxide at room temperature. AAS pastes were prepared using a mixture of activators with five different silicate modules 1 , 
1.2, 1.4, 1.6, and 1.8 and 3 different $\mathrm{Na}_{2} \mathrm{O}$ contents: $6 \%, 8 \%$, and $10 \%$. The authors obtained good workability, with a silicate modulus of 1 and a $\mathrm{Na}_{2} \mathrm{O}$ content of $8 \%$ at room temperature, high compressive strength of $55 \mathrm{MPa}$ and higher, which is explained by the increased total alkali content. It is shown [12] that for all AAS pastes, a fast setting from 9 to 36 minutes, an increase in drying shrinkage with an increase in the silicate modulus are not applicable to the production process.

The paper [13] examines the effect of curing parameters such as pre-cure time, cure time and temperature on the compressive strength of a phosphorus slag cement mortar activated with two different compound activators, including $\mathrm{NaOH}+\mathrm{Na}_{2} \mathrm{CO}_{3}$ and $\mathrm{Na}_{2} \mathrm{CO}_{3}+\mathrm{Ca}(\mathrm{OH})_{2}$, as well as the microstructure, morphology of solidified solutions. It is important to note that the use of high-temperature curing (autoclave $t=175^{\circ} \mathrm{C}$ ) or a combined mode of low-temperature and high-temperature leading to a threefold increase in compressive strength compared to curing conditions in the environment is inexpedient in terms of energy costs and economically unavailable for large-scale construction.

In [14], the effect of phosphorus slag from $10 \%$ to $50 \%$ (by weight) on the setting time and water demand of cement pastes of normal consistency, fluidity, resistance to carbonization and compressive strength of cement slurries was investigated. The compressive strength of the cement slurry was also reduced by the phosphorus slag from $10 \%$ to $50 \%$, and based on the compressive strength of the cement slurry, it was concluded that the activity of the phosphorus slag was low, which is confirmed by its structural feature [1].

Considering that phosphorus slags are extremely valuable raw materials used as the main component or mineral additive in the production of clinker-free (slag-alkali) binders, slag Portland cement and Portland cement, the papers $[15,16]$ consider all known structural and physical and mechanical characteristics of granular phosphorus slags, including phase, as well as effective ways to neutralize them from harmful gases $\left(\mathrm{PH}_{3}, \mathrm{H}_{2} \mathrm{~S}, \mathrm{HF}\right.$, etc.) by reviewing the known theoretical and experimental studies.

As the results of the above studies show, in order to obtain active binders and improve the physical and mechanical properties of granular phosphorus slags, taking into account their inertness, alkaline additives (in the form of pure chemical compounds) are mainly proposed, obtained separately or more often by mixing alkaline activators from sodium silicate and sodium hydroxide with a total content of $\mathrm{Na}_{2} \mathrm{O}$ in the mixture of $10 \%$ and more, which provide high strength indicators and lead to increased viscosity, which affects the reduction of the setting time and excludes the introduction of a production technological process.

It is important to note that the use of high-temperature curing (autoclave $t=175^{\circ} \mathrm{C}$ ) or a combined mode of low-temperature and high-temperature leading to a threefold increase in compressive strength compared to curing conditions in the environment is inexpedient in terms of energy costs and economically unavailable for large-scale construction. It is known that salts containing $\mathrm{MgCl}_{2}, \mathrm{CaCl}_{2}$ chlorides, carnalite, natural bischofite negatively affect corrosion resistance and require additional introduction of inhibitors.

\section{The aim and objectives of the study}

The aim of the study is the development of highly active phosphorus slag binders of hydrothermal and normal hardening at low consumption of deficient alkaline additives [16]

To achieve the aim, the following objectives were set:

- selection of the composition of small amounts of sodium hydroxide with pure alkali metal salts, the anions of which form poorly soluble compounds with calcium;

- selection of a composition of small amounts of sodium hydroxide with waste containing compounds corresponding in composition to model salts of alkali metals, the anions of which form poorly soluble compounds with calcium;

- study of the effect of sodium hydroxide, salts, depending on their nature, concentration on strength under normal conditions;

- study of the effect of cement, salts, depending on their nature, concentration on strength under normal conditions.

\section{Materials and methods of research}

As binders, phosphorus slag binders (non-annealed binders) obtained by grinding granulated electrothermophosphorus slag (Taraz, "United Phosphorus", Republic of Kazakhstan), with activating components, neutralizing additives or without them, depending on the field of application, were used. In the second case, the activation of the slag occurs in the concrete mixture by activating components supplied to the concrete mixer in a dissolved state with mixing water (for example, salt) or in a solid state through a dispenser (cement) (Table 1).

Table 1

Chemical composition of phosphorous slag (no phosphine)

\begin{tabular}{|c|c|c|c|c|c|c|c|c|c|}
\hline \multirow{2}{*}{ Material } & \multicolumn{7}{|c|}{ Chemical composition, wt. \% } \\
\cline { 2 - 10 } & $\mathrm{SiO}_{2}$ & $\mathrm{Al}_{2} \mathrm{O}_{3}$ & $\mathrm{Fe}_{2} \mathrm{O}_{3}$ & $\mathrm{CaO}$ & $\mathrm{MgO}$ & $\mathrm{SO}_{3}$ & $\mathrm{~F}$ & $\mathrm{C} 1$ & sum \\
\hline $\begin{array}{c}\text { Electrothermophosphorus } \\
\text { slag }\end{array}$ & 42.68 & 0.74 & 0.17 & 41.18 & 4.55 & 0.4 & 1.8 & - & 91.57 \\
\hline
\end{tabular}

Cement of the Kant cement plant (Kant, Kyrgyz Republic), sodium hydroxide, and salts were used as activators. The salts used were sulfate, sulfite, carbonate, phosphate, and sodium oxalate, potassium fluoride, and a synthetic soda-sulfate mixture (SSM) containing $30 \%$ soda and $70 \%$ sodium sulfate. The salts used by us are able to activate phosphorus slag in autoclave conditions, allowing us to obtain binders with the strength in the test in the range of $60-90 \mathrm{MPa}$ [4]. But when steaming and under normal conditions, only salts that hydrolyze in an aqueous medium to form an alkali, such as phosphates and carbonates of alkali metals, have an activating ability.

The samples were formed with the dimensions of $4 \times 4 \times 16 \mathrm{~cm}$ from ground slag with a specific surface area of $300-350 \mathrm{~m}^{2} / \mathrm{kg}$, closed with a solution of alkali and salt at $\mathrm{V} / \mathrm{V}=0.21-0.22$. Compaction of the mixtures was carried out on a standard vibration platform for $650 \mathrm{~s}$, steaming at $95{ }^{\circ} \mathrm{C}$ according to the regime of $2+7+2 \mathrm{~h}$. Samples that hardened under normal conditions were stored under water in hermetically sealed baths. The strength test of the binders was carried out according to GOST 310.4-81 "Cements. Methods of bending and compression strength determination" [17] (Table 2). 
Table 2 mation of an equally strong cementing bond. In order to

Physical and mechanical properties of cement of the Kant cement plant

\begin{tabular}{|c|c|c|}
\hline Indicator & $\begin{array}{c}\text { Normative } \\
\text { document }\end{array}$ & Actual value \\
\hline $\begin{array}{c}\text { Fineness of grinding } \\
\text { through the sieve No. 008, \% }\end{array}$ & At least 85 & 93.16 \\
\hline Normal density, \% & - & 24.75 \\
\hline Setting time, hour-min: & $\begin{array}{c}\text { not earlier than } \\
0-45 \\
\text { no later than } \\
10-00\end{array}$ & $0-50$ \\
start & $7-53$ \\
\hline $\begin{array}{c}\text { Strength at the age of } \\
\text { 28 days, kgf/cm²: } \\
\text { bending } \\
\text { compression }\end{array}$ & $\begin{array}{c}\text { At least 8,554 } \\
\text { At least 85,392 }\end{array}$ & $\begin{array}{c}60.8 \\
402.3\end{array}$ \\
\hline
\end{tabular}

As a fine aggregate, feldspar sands of the Nikolaevsky and Kapchagay deposits of the Republic of Kazakhstan were used (Table 3).

Table 3

Physical and mechanical properties of sand

\begin{tabular}{|c|c|c|c|}
\hline Properties & $\begin{array}{c}\text { Unit of } \\
\text { mea- } \\
\text { sure }\end{array}$ & $\begin{array}{c}\text { Nikolaevsky quarry } \\
\text { (Almaty region, } \\
\text { Republic of } \\
\text { Kazakhstan) }\end{array}$ & $\begin{array}{c}\text { Kapchagay quarry } \\
\text { (Almaty region, } \\
\text { Republic of } \\
\text { Kazakhstan) }\end{array}$ \\
\hline Bulk density & $\mathrm{kg} / \mathrm{m}^{3}$ & 1.510 & 1.515 \\
\hline True density & $\mathrm{kg} / \mathrm{m}^{3}$ & 2.67 & 2.60 \\
\hline $\begin{array}{c}\text { Content of } \\
\text { dust and clay } \\
\text { particles }\end{array}$ & $\mathrm{wt}, \%$ & 2.0 & 2.9 \\
\hline
\end{tabular}

The specific surface area of ground slag and slag binder was not less than $300 \mathrm{~m}^{2} / \mathrm{kg}$ or not more than $5 \%$ of the residue on the sieve $\mathrm{N} 008$.

For the study, 2 systems were taken:

1) "slag-sodium hydroxide-salt";

2) "slag-portland cement-salt".

In the course of the study, the influence of cement, sodium hydroxide, and salts, depending on their nature and concentration, on the strength was studied.

The activity (grade) of the slag binder was determined similarly to the activity of cement GOST 310.4-81 "Methods of bending and compression strength determination", based on a mortar mixture consisting of one part of the binder and three parts of sand (1:3).

Cinder-alkaline binders consist of neoplasms in the form of sodium-calcium hydrosilicates or hydroaluminosilicates [5]. A method for activating blast furnace-slag binders with small amounts of alkaline compounds was proposed by [17], but was not widely developed. It is known [4] that during the hydration of slag under autoclave conditions in the presence of small amounts of activators, calcium hydrosilicates of type $\mathrm{CSH}(\mathrm{B})$ or tobermorite are formed with the for- accelerate the process of transformation of vitreous monobasic calcium silicate into hydrated compounds, studies on the effect of activators on strength were carried out under normal conditions $\left(18-23^{\circ} \mathrm{C}\right.$ after $3,7,28$ days) and under curing conditions at $95^{\circ} \mathrm{C}$ according to the $2+7+2 \mathrm{~h}$ regime. The kinetics of alkaline activation of phosphorus slag cement according to the data of compressive strength was studied [6].

The temperature of the slag samples from different batches was in the range of $50.0-70.0 \mathrm{MPa}$ with an alkali content of $1-4 \%$.

In the presence of $0.5 \%$, the strength was lower $(25-$ $30 \mathrm{MPa}$ ). Samples of binders of normal hardening at the age of 28 days with a sodium hydroxide content of $0.5 ; 1.0$; 2 and $4 \%$ had the strength of $20.3 ; 35.4 ; 45.6 ; 55.8 \mathrm{MPa}$, respectively, at the age of 7 days with the same amounts of activator, it was equal to $3.4 ; 5.5 ; 9.11$ and $13.2 \mathrm{MPa}$ [18].

When assessing the activity of binders by the strength of mortar samples on standard sand and freshly obtained slag (composition 1:3 at $\mathrm{V} / \mathrm{V}=0.36$ ), it was found that their strength in the presence of $1-2 \%$ sodium hydroxide by weight of the slag after curing is $20.0-30.0 \mathrm{MPa}$. Low-alkali solutions on PSB are characterized by a slow strength gain in the early stages of hardening, especially for mature slags [19].

Thus, small amounts of alkalis (1-4\%) allow us to obtain PSB with sufficient activity. The effect of the combined presence of alkali and salt is particularly noticeable for small amounts of sodium hydroxide.

It was found that in an alkaline environment, sodium sulfate dramatically increases the activity of binders under curing conditions. For example, with the addition of $1.0 \%$ alkali and 1-2\% salt, the strength of the samples was 67.0 69.0 $\mathrm{MPa}$ after curing. At $4 \%$ sodium sulfate, the strength of the samples did not increase in comparison with binders with a lower salt content (Table 4).

Table 4

Activity of binders in the "slag-sodium hydroxide-salt" system $(\mathrm{V} / \mathrm{V}=0.21-0.22)$

\begin{tabular}{|c|c|c|c|c|c|c|c|c|c|}
\hline \multicolumn{2}{|c|}{$\begin{array}{c}\text { Amount of actie } \\
\text { vators, wt. } \%\end{array}$} & \multicolumn{4}{|c|}{ Bending strength, $\mathrm{MPa}$} & \multicolumn{4}{|c|}{ Compressive strength, $\mathrm{MPa}$} \\
\hline \multirow{2}{*}{$\begin{array}{c}\text { Sodium } \\
\text { hydroxide }\end{array}$} & \multirow{2}{*}{ Salt } & \multicolumn{3}{|c|}{ Normal conditions } & \multirow{2}{*}{$\begin{array}{l}t=95^{\circ} \mathrm{C} \\
2+7+2 \mathrm{~h}\end{array}$} & \multicolumn{3}{|c|}{ Normal conditions } & \multirow{2}{*}{$\begin{array}{l}t=95^{\circ} \mathrm{C} \\
2+7+2 \mathrm{~h}\end{array}$} \\
\hline & & 3 days & 7 days & 28 days & & 3 days & 7 days & 28 days & \\
\hline \multicolumn{10}{|c|}{ Sodium carbonate } \\
\hline 1.0 & 2.0 & 3.8 & 5.0 & 9.0 & 8.4 & 26.0 & 71.2 & 90.1 & 82.0 \\
\hline 1.0 & 1.0 & 3.6 & 6.7 & 7.0 & 8.5 & 26.3 & 72.0 & 82.3 & 80.0 \\
\hline 1.0 & 0.5 & 3.7 & 5.4 & 6.3 & 7.0 & 19.0 & 64.0 & 72.0 & 98.0 \\
\hline \multicolumn{10}{|c|}{ Potassium fluoride } \\
\hline 1.0 & 2.0 & 4.1 & 4.2 & 8.2 & 6.4 & 32.0 & 54.0 & 80.0 & 90.4 \\
\hline 1.0 & 1.0 & 4.0 & 8.5 & 6.6 & 10.3 & 32.0 & 54.0 & 70.0 & 89.0 \\
\hline 1.0 & 0.5 & 5.0 & 7.9 & 8.1 & 9.3 & 36.0 & 38.0 & 60.0 & 98.0 \\
\hline \multicolumn{10}{|c|}{ Sodium phosphate } \\
\hline 1.0 & 4.0 & 3.6 & 5.6 & 5.7 & 10.9 & 40.0 & 62.0 & 68.0 & 79.1 \\
\hline 1.0 & 2.0 & 4.7 & 5.7 & 4.8 & 8.1 & 41.0 & 66.3 & 68.0 & 80.0 \\
\hline 1.0 & 1.0 & 4.0 & 4.5 & 4.6 & 6.6 & 36.7 & 52.5 & 65.0 & 80.0 \\
\hline 1.0 & 0.5 & 3.1 & 4.0 & 4.3 & 6.1 & 32.0 & 39.0 & 57.5 & 86.5 \\
\hline \multicolumn{10}{|c|}{ Sodium sulfate } \\
\hline 1.0 & 4.0 & 1.5 & 3.6 & 6.6 & 9.5 & 3.34 & 15.6 & 60.5 & 68.6 \\
\hline 1.0 & 2.0 & 1.7 & 1.3 & 6.1 & 6.9 & 5.5 & 24.0 & 72.0 & 69.0 \\
\hline 1.0 & 1.0 & 2.4 & 4.0 & 7.1 & 10.4 & 7.4 & 32.2 & 57.0 & 67.0 \\
\hline 1.0 & 0.5 & 2.2 & 4.6 & 6.4 & 5.9 & 8.0 & 23.0 & 53.0 & 76.5 \\
\hline
\end{tabular}


The slag-based binder was characterized by sufficiently high strength characteristics under normal conditions.

The strength after 28 days was $53.0-72.0 \mathrm{MPa}, 7$ days $15.0-32.0 \mathrm{MPa}$. It should be noted that the samples of binders of this composition with the content of each activator of $4 \%$ or more after hardening under normal conditions had efflorescence.

In the presence of $1 \%$ sodium hydroxide and $0.5-2.0 \%$ soda, the activity of PSB increased to 72.0-90.0 MPa.

It was shown above that it is possible to obtain PSB with a sufficiently high activity under normal and curing conditions in the presence of small amounts of composite additives.

The composition of the composite additives includes alkali and sodium sulfate or soda. The first of these salts is active mainly under curing conditions, the action of the second one is more effective under normal conditions.

Since under normal conditions, the hardening process of binders is determined primarily by the content of soda, and not sodium sulfate, we made a synthetic soda-sulfate mixture (SSM) with a low content (30\%).

In the slag samples, the soda content varies widely $(25-60 \%)$.

Under normal conditions, with an alkali content of $1-2 \%$ and SSM of $0.5-2 \%$, the strength of the samples reached 28.0-36.0 $\mathrm{MPa}$ after 3 days, 38.0-54.0 $\mathrm{MPa}$ after 7 days, and $60.0-80.0 \mathrm{MPa}$ after 28 days.

The lowest strength was noted for the composition with the content of each activator $2 \%$. The simultaneous presence of even small amounts $(0.5 \%)$ of potassium fluoride and sodium hydroxide dramatically increases the strength of the samples. After 7 and 28 days, it is 36.0 and $60.0 \mathrm{MPa}$, respectively. When the amount of salt increases to $4 \%$, the strength does not change significantly.

The maximum strength parameters were observed at $1 \%$ sodium hydroxide and $0.5-2 \%$ potassium fluoride. The binders of the considered composition are characterized by high strength of 80.0-90.0 MPa under curing conditions, which is obtained at optimal activator contents $(0.5-1 \%$ sodium hydroxide and $1-4 \%$ potassium fluoride).

A mixture of sodium hydroxide and sodium phosphate was used to activate PSB in curing conditions.

A composite additive consisting of $1 \%$ sodium hydroxide and $0.5-4 \%$ sodium phosphate provides the strength of samples at 3 days age in the range of 32.0 $41.0 \mathrm{MPa}$, at 7 days age $-39.0-66.0 \mathrm{MPa}$, at 28 days age $-57.5-68.0$.

The composition of cement with soda turned out to be more effective in its effect on the early hardening of phosphorus slag binders. In this case, the addition of the same amounts of activators made it possible to obtain fast-hardening binders with a strength of 35.0-50.0, 41.0-83.0 and 51.0-78.0 MPa after 3, 7 and 28 days, respectively. With a constant cement content, the strength increases with an increase in the amount of soda in the range of $1-4 \%$. The effect of cement with a constant content of the salt component is less pronounced.

A similar relationship takes place in the curing conditions. The maximum strength values $(72.0-84.0 \mathrm{MPa})$ were observed at the content of $2-4 \%$ cement and soda. The strength of the samples based on different slags did not differ significantly. The mechanisms of hydration of composite binders containing phosphorus slag at different temperatures are given in the work [20].
Binders containing a composition of cement with a synthetic soda-sulfate mixture showed slightly lower strength after curing. With a constant cement content $(2-4 \%)$, the strength indicators increase with an increase in the proportion of the salt additive, reaching its maximum value at $4 \%(60.0-65.0 \mathrm{MPa})$.

A similar dependence of strength on the content of activators is observed for binders that harden under normal conditions.

At the same time, the strength of the samples hardening during 3 and 7 days reaches $30.0-45.0$ and $60.0 \mathrm{MPa}$, respectively.

The strength parameters of the samples with the addition of salt and water after 3 days of storage do not differ significantly.

The strength of binders after 28 days, as well as after curing, is significantly lower compared to binders containing soda.

Binders activated with $4 \%$ cement and $1-2 \%$ potassium fluoride had a strength of 58.0 and $72.0 \mathrm{MPa}$, respectively, after curing (Table 5), which is $1.8-2.8$ times higher than the strength of samples with the addition of only the first activator.

After 7 and 28 days, it is $25.0-37.0 \mathrm{MPa}$ and $46.0-$ $70.0 \mathrm{MPa}$, respectively. When the amount of salt increases to $4 \%$, the strength does not change significantly.

The maximum strength values were observed at $2-4 \%$ cement and $2-4 \%$ potassium fluoride.

Table 5

Activity of binders in the "slag-Portland cement-salt" system $(\mathrm{V} / \mathrm{V}=0.21=0.22)$

\begin{tabular}{|c|c|c|c|c|c|c|c|c|c|}
\hline \multicolumn{2}{|c|}{$\begin{array}{c}\text { Amount of activa- } \\
\text { tors, wt. } \%\end{array}$} & \multicolumn{4}{|c|}{ Bending strength, MPa } & \multicolumn{4}{|c|}{$\begin{array}{c}\text { Compressive } \\
\text { strength, } \mathrm{MPa}\end{array}$} \\
\hline \multirow{2}{*}{$\begin{array}{c}\text { Portland } \\
\text { cement }\end{array}$} & \multirow[t]{2}{*}{ Salt } & \multicolumn{3}{|c|}{\begin{tabular}{c|c|} 
Normal \\
conditions, days: \\
\end{tabular}} & \multirow{2}{*}{$\begin{array}{l}t=95^{\circ} \mathrm{C} \\
2+7+2 \mathrm{~h}\end{array}$} & \multicolumn{3}{|c|}{$\begin{array}{c}\text { Normal } \\
\text { conditions, days: }\end{array}$} & \multirow{2}{*}{$\begin{array}{l}t=95^{\circ} \mathrm{C} \\
2+7+2 \mathrm{~b}\end{array}$} \\
\hline & & 3 & 7 & 28 & & 3 & 7 & 28 & \\
\hline \multicolumn{10}{|c|}{ Sodium carbonate } \\
\hline 4.0 & 4.0 & 4.3 & 5.0 & 9.2 & 5.5 & 50.0 & 83.5 & 78.0 & 54.0 \\
\hline 4.0 & 2.0 & 4.7 & 5.4 & 10.2 & 8.3 & 47.0 & 64.0 & 68.0 & 76.0 \\
\hline 4.0 & 1.0 & 3.2 & 4.8 & 8.2 & 7.2 & 41.0 & 50.0 & 58.5 & 64.0 \\
\hline 4.0 & 0.5 & 2.9 & 2.9 & 7.1 & 6.8 & 35.0 & 41.0 & 51.0 & 53.0 \\
\hline \multicolumn{10}{|c|}{ Potassium fluoride } \\
\hline 4.0 & 4.0 & 5.5 & 6.7 & 9.0 & 10.9 & 37.0 & 53.0 & 75.0 & 80.0 \\
\hline 4.0 & 2.0 & 3.6 & 5.7 & 10.6 & 9.9 & 25.0 & 37.0 & 70.0 & 72.0 \\
\hline 4.0 & 1.0 & 3.0 & 3.6 & 5.9 & 60.1 & 17.0 & 25.0 & 46.0 & 58.0 \\
\hline 4.0 & 0.5 & 2.8 & 3.1 & 5.7 & 3.8 & 13.0 & 16.0 & 34.0 & 36.0 \\
\hline \multicolumn{10}{|c|}{ Sodium phosphate } \\
\hline 4.0 & 4.0 & 3.0 & 3.8 & 6.3 & 7.2 & 23.0 & 44.0 & 60.0 & 75.0 \\
\hline 4.0 & 2.0 & 2.9 & 3.5 & 6.1 & 6.3 & 17.2 & 43.0 & 62.0 & 68.0 \\
\hline 4.0 & 1.0 & 1.7 & 3.8 & 5.7 & 6.8 & 14.1 & 43.5 & 50.0 & 54.0 \\
\hline 4.0 & 0.5 & 1.5 & 2.0 & 4.3 & 5.0 & 12.0 & 28.0 & 38.0 & 41.0 \\
\hline \multicolumn{10}{|c|}{ Sodium sulfate } \\
\hline 4.0 & 4.0 & 3.4 & 4.5 & 7.0 & 7.3 & 12.0 & 23.0 & 58.0 & 68.0 \\
\hline 4.0 & 2.0 & 2.5 & 4.0 & 8.0 & 6.5 & \begin{tabular}{|l|}
9.0 \\
\end{tabular} & 19.0 & 50.0 & 56.0 \\
\hline 4.0 & 1.0 & 2.3 & 3.5 & 5.0 & 7.1 & 8.0 & 14.0 & 38.0 & 49.0 \\
\hline 4.0 & 0.5 & 2.0 & 3.0 & 4.8 & 3.8 & 7.0 & 12.0 & 30.0 & 34.0 \\
\hline
\end{tabular}

The binders of the composition under consideration are characterized by high strength both under curing and normal conditions, which, at optimal activator contents ( $4 \%$ 
cement and 2-4\% potassium fluoride), reaches $72.0-80.0 \mathrm{MPa}$ under curing and 70.0-75.0 MPa under normal conditions, respectively.

A composition of cement with sodium phosphate was also used to activate the phosphorus slag binders under curing and normal conditions [21].

The strength characteristics of the binders of the "slag-cement-sodium phosphate" system are determined by the quantitative ratio of activators.

Small amounts of salt $0.5-1 \%$ do not cause hardening of the binders at $2-4 \%$ cement content when stored for 7 days.

After 28 days, these samples had a strength of 16.0-23.0 and 38.0-50.0 MPa, respectively. A higher phosphate content (2\%) with $4 \%$ cement addition contributes to a significant increase in strength up to $62.0 \mathrm{MPa}$.

In the curing conditions, a similar pattern is observed: an increase in the amount of salt from 0.5 to $4 \%$ causes an increase in strength from 54.0 to $75.0 \mathrm{MPa}$ with $4 \%$ cement addition. The binding compositions "Portland cement-sodium sulfate" are characterized by sufficiently high strength indicators and in normal conditions their strength after 28 days was $30.0-58.0 \mathrm{MPa}$. It is important to note a more beneficial effect of curing in comparison with normal conditions on this system. The strength of the samples after curing was 34.0-68.0 MPa.

As can be seen from Table 6, the addition of alkali increases the $\mathrm{pH}$, and the alkaline balance of sodium sulfate increases to a greater extent than that of sodium carbonate. When adding the compositions $(\mathrm{NaOH}+$ salt $)$ to the slag, the $\mathrm{pH}$ of the silicate system decreases significantly after 48 hours.

Knowing the limits of the existence of various forms of orthosilicic acid and its ions according to the ideas [22], the content of the following individual forms of orthosilicic acid can be determined depending on the $\mathrm{pH}$ value in the systems under study.

Influence of the nature of activators on $\mathrm{pH}$

\begin{tabular}{|c|c|c|c|c|c|c|}
\hline \multirow{2}{*}{ Salt } & & $\mathrm{pH}$ & \multirow{2}{*}{$\begin{array}{c}\mathrm{NaOH}+\text { salt" } \\
\text { composition }\end{array}$} & $\mathrm{pH}$ & $\begin{array}{c}\text { "Slag }+\mathrm{NaOH}+\text { salt" } \\
\text { system }\end{array}$ & \multicolumn{2}{|c|}{$\begin{array}{c}\mathrm{pH} \text { value } \\
\text { after, hour }\end{array}$} \\
\cline { 6 - 8 } & & & 1 & 48 \\
\hline $\mathrm{Na}_{2} \mathrm{CO}_{3}$ & 9.2 & $\mathrm{NaOH}+\mathrm{Na}_{2} \mathrm{CO}_{3}$ & 11.6 & Slag $+\mathrm{NaOH}+\mathrm{Na}_{2} \mathrm{CO}_{3}$ & 11.0 & 9.71 \\
\hline $\mathrm{KF}$ & 7.4 & $\mathrm{NaOH}+\mathrm{KF}$ & 12.7 & $\mathrm{Slag}+\mathrm{NaOH}+\mathrm{KF}$ & 12.2 & 10.3 \\
\hline $\mathrm{Na}_{3} \mathrm{PO}_{4}$ & 7.1 & $\mathrm{NaOH}+\mathrm{Na}_{3} \mathrm{PO}_{4}$ & 13.0 & Slag $+\mathrm{NaOH}+\mathrm{Na}_{3} \mathrm{PO}_{4}$ & 12.5 & 11.0 \\
\hline $\mathrm{Na}_{2} \mathrm{SO}_{4}$ & 6.7 & $\mathrm{NaOH}+\mathrm{Na}_{2} \mathrm{SO}_{4}$ & 13.2 & Slag $+\mathrm{NaOH}+\mathrm{Na}_{2} \mathrm{SO}_{4}$ & 13.0 & 11.8 \\
\hline
\end{tabular}

In the slag system $-\mathrm{NaOH}-\mathrm{Na}_{2} \mathrm{CO}_{3}-\mathrm{H}_{2} \mathrm{O}$, the $\mathrm{pH}$ ranges from 9.7-11.0, therefore, in this system, silicon-oxygen radicals are mainly represented by $\mathrm{H}_{4} \mathrm{SiO}_{4}, \mathrm{H}_{3} \mathrm{SiO}_{4}^{1-}, \mathrm{H}_{2} \mathrm{SiO}_{4}^{2-}$.

In the slag system $-\mathrm{NaOH}-\mathrm{KF}-\mathrm{H}_{2} \mathrm{O}$, the $\mathrm{pH}$ is $10.3 \ldots 12.2$, orthosilicic acid is represented by $\mathrm{H}_{2} \mathrm{SiO}_{4}^{2-}, \mathrm{HSiO}_{4}^{3-}$.

In the slag system $-\mathrm{NaOH}-\mathrm{Na}_{3} \mathrm{PO}_{4}-\mathrm{H}_{2} \mathrm{O}, \mathrm{pH}=11.0 \ldots 12.5$, and orthosilicic acid will be represented as the following radicals: $\mathrm{H}_{2} \mathrm{SiO}_{4}^{2-}, \mathrm{HSiO}_{4}^{3-}, \mathrm{SiO}_{4}^{4-}$, slag system $\mathrm{NaOH}-\mathrm{Na}_{2} \mathrm{SO}_{4}\left(\mathrm{pH}\right.$ 11.8...13.0)- $\mathrm{HSiO}_{4}^{3-}, \mathrm{SiO}_{4}^{4-}$.

The strength in the obtained systems varies in the series (MPA): $\mathrm{CaCO}_{3}(70)>\mathrm{CaF}_{2}(60)>\mathrm{Ca}_{3}\left(\mathrm{PO}_{4}\right)_{2}(50)>$ $>\mathrm{CaSO}_{4}(30)$.

The hydration and strength of the binder depend on the nature of the anion forming poorly soluble compounds.
A number of strength parameters correspond to a number of values of the dissociation constants of the acids forming the corresponding solid bases in the system: $\mathrm{KH}_{2} \mathrm{CO}_{3}$ $\left(4.4 \times 10^{-7}\right)<\mathrm{KHF} \quad\left(6.6 \times 10^{-4}\right)<\mathrm{KH}_{3} \mathrm{PO}_{4} \quad\left(7.5 \times 10^{-3}\right)<$ $<\mathrm{KH}_{2} \mathrm{SO}_{4}\left(2 \times 10^{3}\right)[22,23]$.

The highest degree of silicic acid polymerization in the "slag- $\mathrm{NaOH}-\mathrm{Na}_{2} \mathrm{CO}_{3}-\mathrm{H}_{2} \mathrm{O}$ " system, expressed by the formation of a large number of different forms of orthosilicic acid in comparison with other systems considered, explains its first position in the strength series.

The formation of only two forms of orthosilicic acid in the "slag- $\mathrm{NaOH}+\mathrm{Na}_{2} \mathrm{SO}_{4}-\mathrm{H}_{2} \mathrm{O}$ " system explains the lowest activity of the obtained binder.

Probably, the hardly soluble compounds formed act on the principle of acid-base catalysts [24] the $\mathrm{pH}$ of the medium of the alkaline systems, which, in turn, affects the degree of polymerization, accelerates the main reactions of hydration of silicates.

\section{Research results of the influence of the composition of activators on phosphorus slag binders}

5. 1. Selection of the composition of small amounts of sodium hydroxide with pure alkali metal salts

The selected and used pure salts of sulfate, sulfite, carbonate, sodium phosphate, potassium fluoride by anion formed poorly soluble compounds: $\mathrm{CaCO}_{3}, \mathrm{CaF}_{2}$, $\mathrm{Ca}_{3}\left(\mathrm{PO}_{4}\right)_{2}, \mathrm{CaSO}_{4}$.

The effect of the combined presence of alkali and salt is especially noticeable for small amounts of sodium hydroxide. It was found that in an alkaline medium, the activity of binders is higher at a lower salt content under curing conditions $(0.5 \%)$ than under normal conditions $(2 \%)$. With the addition of $1.0 \%$ alkali and $0.5 \%$ salt, the strength of the samples

Table 6 after curing (MPa) was: (98) $\mathrm{Na}_{2} \mathrm{CO}_{3}>(98) \mathrm{KF}>$ $>$ (86) $\mathrm{Na}_{3} \mathrm{PO}_{4}>$ (76) $\mathrm{Na}_{2} \mathrm{SO}_{4}$, and under normal conditions with the addition of $1.0 \%$ alkali and $2 \%$ salt, the strength of the samples was: (90) $\mathrm{Na}_{2} \mathrm{CO}_{3}>$ $>$ (80) $\mathrm{KF}>(72) \mathrm{Na}_{2} \mathrm{SO}_{4}>$ (68) $\mathrm{Na}_{3} \mathrm{PO}_{4}$.

5. 2. Selection of the composition of small amounts of sodium hydroxide with waste containing the corresponding compounds

Selected and used soda-sulfate waste from caprolactam production - soda-sulphate mixture SSM containing $30 \%$ soda and $70 \%$ sodium sulfate, by-products of superphosphate plants containing low sodium fluoride, sodium fluoride and sodium phosphate by anion formed difficult-to-dissolve compounds: $\mathrm{CaCO}_{3}, \mathrm{CaF}_{2}, \mathrm{Ca}_{3}\left(\mathrm{PO}_{4}\right)_{2}, \mathrm{CaSO}_{4}$.

A similar dependence of strength on the content of activators is observed for binders containing waste. The hydration and strength of the binder depend on the nature of the anion that forms poorly soluble compounds. The strength in the obtained systems changes in the series (MPA): $\mathrm{CaCO}_{3}(60)>\mathrm{CaF}_{2}(50)>\mathrm{Ca}_{3}\left(\mathrm{PO}_{4}\right)_{2}(50)>\mathrm{CaSO}_{4}(30)$.

5. 3. Study of the effect of sodium hydroxide with pure alkali metal salts under normal conditions

Low-alkaline solutions on phosphorus slag binders are characterized by a slow set of strength in the early stages 
of hardening, especially for aged slags. The strength with a sodium hydroxide content of $1-4 \%$ after curing at $95{ }^{\circ} \mathrm{C}$ according to the $2+7+2 \mathrm{~h}$ mode for slag specimens of various batches was in the range of 50.0-70.0 MPa. Samples of binders of normal hardening at the age of 28 days with a sodium hydroxide content of $0.5 ; 1.0,2$ and $4 \%$ had the strength of $20.3 ; 35.4 ; 45.6 ; 55.8 \mathrm{MPa}$, respectively.

With the addition of $1.0 \%$ alkali and $0.5 \%$ salt, the strength of the samples after curing $(\mathrm{MPa})$ was: (98) $\quad \mathrm{Na}_{2} \mathrm{CO}_{3}>(98) \quad \mathrm{Na}_{2} \mathrm{CO}_{3}>(98) \quad \mathrm{KF}>(86) \quad \mathrm{Na}_{3} \mathrm{PO}_{4}>$ $>(76) \mathrm{Na}_{2} \mathrm{SO}_{4}$, and under normal conditions with the addition of $1.0 \%$ alkali and $2 \%$ salt, the strength of the samples was, (MPa): (98) $\mathrm{Na}_{2} \mathrm{CO}_{3}>(98) \mathrm{KF}>(86) \mathrm{Na}_{3} \mathrm{PO}_{4}>(76) \mathrm{Na}_{2} \mathrm{SO}_{4}$.

5. 4. Study of the effect of cement with pure alkali metal salts under normal conditions

Binders containing a composition of cement with salts under normal conditions and after curing showed a slightly lower strength than in an alkaline medium. At a constant cement content (4\%), the strength indicators increase with an increase in the proportion of the salt additive, reaching at $4 \%$ its maximum value (MPa): (98) $\mathrm{Na}_{2} \mathrm{CO}_{3}>(98) \mathrm{KF}>(86)$ $\mathrm{Na}_{3} \mathrm{PO}_{4}>(76) \mathrm{Na}_{2} \mathrm{SO}_{4}$ under normal conditions.

\section{Discussion of experimental results of the production technology of phosphorus slag binders}

The research results according to all the assigned tasks from the problem area are clearly shown in section 5 , in the text of the paper, in Tables 4,5. This work shows us the proposed way to solve the problem, an alternative way is the choice for our colleagues.

The technology for the production of phosphorus slag binders is based on the theoretical prerequisites for the destruction of silicon and calcium-oxygen polyhedral groups of slag under the influence of various activating components.

The use of alkali metal salts, the anions of which form poorly soluble compounds with calcium of phosphorus slag in a composition with a low content of sodium hydroxide, which has a pronounced activating ability and reduces the degree of hydrolysis of sodium metasilicate, makes it pos- sible to achieve high strength parameters and setting times required for their industrial use.

The addition of chemically pure sodium hydroxide as an alkaline component to the system limits its use on a construction scale.

The inconsistency of the existing regulatory documents that allow obtaining binders without cleaning and non-permissive ones requires additional research in different countries to develop a unified approach.

In connection with the tightening of requirements for environmental and sanitary standards, the absence of a database on waste that could be used as activating components.

\section{Conclusions}

1. The hydration and strength of the binder depend on the nature of the anion that forms poorly soluble compounds. The strength in the obtained systems changes in the series (MPA): $\mathrm{CaCO}_{3}(70)>\mathrm{CaF}_{2}(60)>\mathrm{Ca}_{3}\left(\mathrm{PO}_{4}\right)_{2}(50)>\mathrm{CaSO}_{4}(30)$.

2 . The effect of the nature of activators on $\mathrm{pH}$ was determined. The content of individual forms of orthosilicic acid is assumed depending on the $\mathrm{pH}$ value in the systems under study.

3. A number of strength indicators correspond to a number of values of the dissociation constants of acids forming the corresponding solid bases in the system: $\mathrm{KH}_{2} \mathrm{CO}_{3}$ $\left(4.4 \times 10^{-7}\right)<\mathrm{KHF} \quad\left(6.6 \times 10^{-4}\right)<\mathrm{KH}_{3} \mathrm{PO}_{4} \quad\left(7.5 \times 10^{-3}\right)<$ $<\mathrm{KH}_{2} \mathrm{SO}_{4}\left(2 \times 10^{3}\right)$. Thus, alkali metal salts, the anions of which form poorly soluble compounds with calcium, when used together with a small amount of alkali, make it possible to obtain highly active alkali-alkali binders that harden under normal and curing conditions.

4. The data obtained indicate the advantages of using phosphorus slag binders and various industrial waste with a low content of alkaline compounds in the production. Such wastes are alkaline solutions of coke-chemical industries, solutions obtained during air purification at metallurgical plants, waste products from $\beta$-naphthol production, soda sulfate waste from caprolactam production, waste soda production, by-products of superphosphate plants.

\section{References}

1. Estemesov, Z. A., Sadykov, P. I., Barvinov, A. V., Sarsenbaev, N. B., Estemesov, M. Z., Uralkhanova, A. U., Tulaganov, A. A. (2020). Physical and chemical processes occurring in the granulated phosphorus slag dumps. New 'of the national academy of sciences of the republic of Kazakhstan. Series chemistry and technology, 2 (440), 47-55. doi: http://doi.org/10.32014/2020.2518-1491.22

2. Taghvayi, H., Behfarnia, K., Khalili, M. (2018). The Effect of Alkali Concentration and Sodium Silicate Modulus on the Properties of Alkali-Activated Slag Concrete. Journal of Advanced Concrete Technology, 16 (7), 293-305. doi: http://doi.org/10.3151/ jact.16.293

3. Mehdizadeh, H., Kani, E. N. (2018). Modeling the influence of chemical composition on compressive strength behavior of alkaliactivated phosphorus slag cement using statistical design. Canadian Journal of Civil Engineering, 45 (12), 1073-1083. doi: http:// doi.org/10.1139/cjce-2018-0132

4. Glukhovskii, V. D., Pakhomov, V. A. (1978). Shlakoschelochnye tsementy i betony. Kyiv: Budivelnik, 184.

5. Aymenov, A. Z., Sarsenbayev, N. B., Khudyakova, T. M., Sarsenbayev, B. K., Batyrkhanov, A. T., Kopzhassarov, B. T. (2016). Effect of Additive of Polymetallic Ores' Tailin gs on Properties of Composite Cements. Eurasian Chemico-Technological Journal, 18 (2), 153-160. doi: http://doi.org/10.18321/ectj442

6. Shintemirov, K. S., Urazova, S. S. Concrete on phosphors slag binder, activated salts of alkali and alkaline earth metals. West Kazakhstan agrarian - technical university name of Zhangir Khan. Available at: https://pandia.ru/text/80/594/30159.php

7. Tong, S., Yuqi, Z., Qiang, W. (2021). Recent advances in chemical admixtures for improving the workability of alkali-activated slagbased material systems. Construction and Building Materials, 272, 121647. doi: http://doi.org/10.1016/j.conbuildmat.2020.121647 
8. Criado, M., Ke, X., Provis, J. L., Bernal, S. A. (2017). Alternative inorganic binders based on alkali-activated metallurgical slags. Sustainable and Nonconventional Construction Materials Using Inorganic Bonded Fiber Composites, 185-220. doi: http:// doi.org/10.1016/b978-0-08-102001-2.00008-5

9. Sarsenbayev, N. B., Sarsenbayev, B. K., Aubakirova, T. S., Aimenov, J. T., Abdiramanova, K. S. (2014). Phase Composition and Structure-Formation of the Low-Clinkered Floured Cements. Eurasian Chemico-Technological Journal, 16 (4), 333-338. doi: http://doi.org/10.18321/ectj2

10. Mehdizadeh, H., Kani, E. N. (2018). Modeling the influence of chemical composition on compressive strength behavior of alkaliactivated phosphorus slag cement using statistical design. Canadian Journal of Civil Engineering, 45 (12), 1073-1083. doi: http:// doi.org/10.1139/cjce-2018-0132

11. Jiao, Z., Wang, Y., Zheng, W., Huang, W. (2018). Effect of Dosage of Alkaline Activator on the Properties of Alkali-Activated Slag Pastes. Advances in Materials Science and Engineering, 2018, 1-12. doi: http://doi.org/10.1155/2018/8407380

12. Maghsoodloorad, H., Khalili, H., Allahverdi, A. (2018). Alkali-Activated Phosphorous Slag Performance under Different Curing Conditions: Compressive Strength, Hydration Products, and Microstructure. Journal of Materials in Civil Engineering, 30 (1), 04017253. doi: http://doi.org/10.1061/(asce)mt.1943-5533.0002101

13. Purdon, A. O. (1940). The action of alkalis on blast furnace slag. Journal of the Society of Chemical Industry, 59, 35-37.

14. Pang, M., Sun, Z., Chen, M., Lang, J., Dong, J., Tian, X., Sun, J. (2020). Influence of Phosphorus Slag on Physical and Mechanical Properties of Cement Mortars. Materials, 13 (10), 2390. doi: http://doi.org/10.3390/ma13102390

15. Estemessov, Z. A. (2020). Effect of 3d-metal saltson the activity of ecophosphate slag blnding agents. NEWS Of the academy of sciences of the republic of kazakhstan Satbayev University, 3 (441), 177-181. doi: http://doi.org/10.32014/2020.2518-170x.69

16. Makhambetova, U. K. (1989). Aktivirovannoe tverdenie fosfornoshlakovykh viazhuschikh. Leningrad, 243. Available at: https:// search.rsl.ru/ru/record/01008098177

17. Maghsoodloorad, H., Allahverdi, A. (2017). Developing Low-Cost Activators for Alkali-Activated Phosphorus Slag-Based Binders. Journal of Materials in Civil Engineering, 29 (6), 04017006. doi: http://doi.org/10.1061/(asce)mt.1943-5533.0001806

18. Mehdizadeh, H., Najafi Kani, E., Palomo Sanchez, A., Fernandez-Jimenez, A. (2018). Rheology of activated phosphorus slag with lime and alkaline salts. Cement and Concrete Research, 113, 121-129. doi: http://doi.org/10.1016/j.cemconres.2018.07.010

19. Maghsoodloorad, H., Allahverdi, A. (2015). Alkali-activation kinetics of phosphorus slag cement using compressive strength data. Ceramics-Silikaty, 59 (3), 250-260.

20. Xu, Z., Yue, J., Pang, G., Li, R., Zhang, P., Xu, S. (2021). Influence of the Activator Concentration and Solid/Liquid Ratio on the Strength and Shrinkage Characteristics of Alkali-Activated Slag Geopolymer Pastes. Advances in Civil Engineering, 2021, 1-11. doi: http://doi.org/10.1155/2021/6631316

21. Makhambetova, U. K., Ibragim, B., Abdullaev, Kh. T., Baimuratova, G. K. (2020). Razrabotka shlakoschelochnogo viazhuschego iz granulirovannogo elektrotermofosfornogo shlaka. Promyshlennii transport Kazakhstana, 2 (67), 153-155.

22. Pang, M., Sun, Z., Chen, M., Lang, J., Dong, J., Tian, X., Sun, J. (2020). Influence of Phosphorus Slag on Physical and Mechanical Properties of Cement Mortars. Materials, 13 (10), 2390. doi: http://doi.org/10.3390/ma13102390

23. Zhang, Z., Wang, Q., Yang, J. (2017). Hydration mechanisms of composite binders containing phosphorus slag at different temperatures. Construction and Building Materials, 147, 720-732. doi: http://doi.org/10.1016/j.conbuildmat.2017.04.202

24. Makhambetova, U. K., Abdullaev, Kh. T., Konysbaeva, Zh. O., Shalabaeva, S. I. (2020). Issledovanie strukturoobrazovaniia v protsesse gidratatsii v shlakoschelochnom viazhuschem. Promyshlennii transport Kazakhstana, 3 (68), 131-135. 